\title{
Problemy badawcze struktury przestrzennej przemysłu
}

W procesie rozwoju każdej dyscypliny naukowej występuje szereg etapów związanych $\mathrm{z}$ coraz precyzyjniejszym poznawaniem przedmiotu badań $\mathrm{w}$ drodze stawiania nowych hipotez, celów i doskonalenia metod badawczych. Wyrażają się one w przechodzeniu od opisu przedmiotu poznania i wyjaśniania jego procesu kształtowania się do wypracowywania modeli i budowy teorii. Można więc przyjąć, że poszczególne nauki w zależności od fazy znajdują się na różnym poziomie rozwoju.

Wyłaniają się stąd cele pracy naukowej, które wiążą się z dążeniem do wypełniania luk w teorii danej dyscypliny wiedzy, poprzez podejmowanie badań zmierzających do wykrycia, uzasadnienia i systematyzacji twierdzeń składających się na naukę $\mathrm{w}$ rozumieniu treściowym, a także z zastosowaniem wypracowanych koncepcji teoretycznych do działań aplikacyjnych. Cele te wynikają z chęci poznania świata, zrozumienia zmieniającej się rzeczywistości, jej struktury, pochodzenia i rozwoju oraz z chęci opanowania rzeczywistości i pokierowania tokiem jej przemian zgodnych z założonymi celami życia człowieka. W pełni staje się to możliwe dopiero dzięki poznaniu rzeczy i rządzących nimi praw (prawidłowości). Racjonalne zarządzanie procesem przemian jest bowiem tym skuteczniejsze, im bardziej opiera się na naukowo uzasadnionych twierdzeniach o obiektywnych zależnościach między wartościami analizowanych cech, tendencjami ich dalszych przemian oraz możliwościami sterowania nimi.

Przyjmujemy, że zbiór poglądów dotyczących danej dziedziny poznania dopiero wtedy zasługuje na miano nauki, kiedy są w niej wyróżnione twierdzenia podstawowe, ze względu na które uzasadnia się twierdzenia pochodne. Tak uporządkowane zbiory poglądów tworzą teorię, którą m.in. na polu geografii przemysłu można wyrazić w konwencji kształtowania się systemów dynamicznych.

W świetle przedstawionych przesłanek wyłania się potrzeba podejmowania prac nad budową teorii geografii przemysłu. Wynika to nie tylko z dążenia do intensyfikacji badań podstawowych, ale także z potrzeb społecznych, które wykorzystują wyniki badań naukowych do celów aplikacyjnych, np. w zakresie budowy strategii rozwoju układów krajowych, regionalnych czy lokalnych. Wychodząc z powyższych założeń, przedmiotem niniejszych rozważań jest próba określenia wybranych problemów badawczych struktury przestrzennej przemysłu. W przedstawionej koncepcji nawiązujemy do ogólnych założeń metodologii nauki i teorii systemów (Beer 1966, Hall 1968, Mynarski 1974, Szymański 1991, Ziemba, Jamrozik, Staniszewski 1980) oraz szeregu prac teoretycznych podejmujących problema- 
tykę budowy teorii geografii (Chojnicki 1970, 1973, 1980, 2004, Chojnicki, Dziewoński 1978, Domański 1967, 1982, Łoboda 2004), podstaw budowy teorii geografii przemysłu (Dobrowolska 1965, Fierla 1992, Leszczycki, Kukliński 1964, Kortus 1981, 1986, Misztal, Zioło 1998, Zioło 1978, 1980, 2007), a także do wielu studiów empirycznych ${ }^{1}$.

Podejmując problematykę budowy teorii struktury przestrzennej przemysłu czy geografii przemysłu, w świetle współczesnych koncepcji metodologii ogólnej należy przyjąć, iż geografia przemysłu w procesie swojego rozwoju (podobnie jak inne dyscypliny wiedzy, np. fizyka) przechodzić będzie kolejne stadia ewolucji. Odznaczają się one zmieniającymi się koncepcjami i wzorcami metodologicznymi zmierzającymi od empirycznej analizy zjawisk, poprzez różne koncepcje myślowe i budowanie cząstkowych teorii do zintegrowanych uogólnień kształtujących teorię danej dyscypliny. Stadia te obejmują: opis zjawisk, pomiar i określenie zależności ilościowo-jakościowych zachodzących między nimi, wykrywanie prawidłowości w kształtowaniu się danego procesu, wyjaśnianie zjawisk przy pomocy wypracowanej teorii, prognozowanie rozwoju analizowanego zjawiska, określenie metod sterowania danym procesem, jego obserwację i wypracowywanie instrumentów korygujących prowadzących proces do jego realizacji zgodnie z założonymi celami społecznymi, gospodarczymi i kulturowymi.

Wstępnie wychodzimy z założenia, że przyszłość geografii przemysłu, podobnie jak i innych dyscyplin naukowych, zależy w znacznym stopniu od wagi rozwiązywanych przez nich problemów naukowych (teoretycznych i aplikacyjnych). Rozwiązywanie ich jest niezbędne dla rozwoju metodologicznego nie tylko geografii przemysłu, ale także innych dyscyplin, których przedmiotem zainteresowania jest przestrzeń geograficzna czy jej wybrane elementy. Obok problemów teoriopoznawczych, rozwój geografii przemysłu uwarunkowany jest w dużym stopniu możliwościami zastosowania jej wyników badawczych w praktyce gospodarczej, głównie poprzez dostarczanie wzorców uzasadnionych teoretycznie i zweryfikowanych empirycznie, które pozwolą na realizację określonych celów polityki przestrzennej, a następnie dostarczanie istotnych informacji dotyczących oceny i przewidywanie procesów rozwojowych w przyszłości, oraz będą podstawą dla podejmowania racjonalnych decyzji. Ogólnie należy przyjąć, iż pozycja geografii przemysłu w systemie nauk związana jest z jej wkładem w rozwiązywanie teoretyczno-poznawczych i społecznie ważnych problemów naukowych wynikających z dokonujących się przemian w strukturze przestrzennej przemysłu. Przy czym efektywność proponowanych rozwiązań zależy w znacznym stopniu od właściwej diagnozy, weryfikacji zakładanych celów rozwojowych i stopnia precyzji wypracowanych metod badawczych.

Teorię naukową należy traktować jako usystematyzowany zbiór twierdzeń logicznie i rzeczowo uporządkowanych, powiązanych określonymi stosunkami logicznymi, dotyczących określonej dziedziny wiedzy, która pomaga wyjaśniać dany zakres rzeczywistości. W poszczególnych dyscyplinach naukowych teorie mają różną strukturę, różny stopień uzasadnienia i spójności wewnętrznej oraz ogólności.

W naukach formalnych (matematyce, logice) teorią nazywa się system twierdzeń składający się ze zbioru aksjomatów (założeń) oraz ich konsekwencji logicznych (system dedukcyjny, system sformalizowany, sformalizowane teorie).

${ }^{1}$ Precyzyjniejsze omówienie przesłanek i literatury zawierają kolejne tomy Prac Komisji Geografii Przemysłu PTG, m.in. Zioło 1988, 1990, 1993, 2001; Zioło, Makieła 2003; Zioło, Rachwał 2006, a także prace dotyczące kształtowania struktur regionalnych, np. Kitowski 2001, 2003. 
W naukach empirycznych teorie danej dziedziny określa się jako:

- zbiór zadań tłumaczących dane zjawiska, tworzący wraz z wyjaśniającymi je prawami naukowymi i hipotezami logicznie zwartą jednostkę wiedzy naukowej w tej dziedzinie,

- wszelki system twierdzeń dotyczących danej dziedziny i zawierających terminy teoretyczne, które odnoszą się do przedmiotów lub własności bezpośrednio nie obserwowanych,

- układ praw nauki, hipotez ogólnych i definicji logicznie, rzeczowo tak powiązanych, że z najogólniejszych spośród nich wyprowadzić można wszystkie inne twierdzenia mniej ogólne, oraz tak sformułowanych, że umożliwiają one empiryczną kontrolę (weryfikację).

W tym ostatnim znaczeniu o teorii nauki mówi się dopiero wtedy, gdy pewien zbiór twierdzeń jednostkowych dotyczących dostatecznie obszernego fragmentu rzeczywistości oraz uogólniające twierdzenia jednostkowe w twierdzenia ogólne (prawa, prawidłowości) znajdują wyjaśnienie w postaci nielicznej grupy niesprzecznych z sobą praw i hipotez. Prawa i hipotezy danej teorii naukowej mogą z kolei mieć wyjaśnienia, dzięki którym wchodzi ona w ramy teorii ogólniejszej.

Między teoriami nauk formalnych a teoriami nauk empirycznych występuje jednak pewne przenikanie. System formalny może być wykorzystany w naukach empirycznych, jeżeli panuje w nich dostateczna analogia do układu stosunków występujących w naukach formalnych, czyli jeżeli obie dziedziny są niejako modelami tego samego schematu formalnego (np. analiza czynników produkcji, relacje między elementami przestrzeni geograficznej czy relacje między elementami przestrzeni przemysłowej). Formalizacja jest jedną z postaci matematyzacji analizy rozwoju kształtowania się systemów naukowych poprzez wykorzystanie rachunku prawdopodobieństwa (twierdzenia wykorzystujące zależności stochastyczne), w drodze przechodzenia danej nauki od analizy zależności jakościowych i poprzez badania zależności ilościowych do ujęć ilościowo-jakościowych. Podejście to wymaga stosowania określonego pomiaru, którego zadaniem jest dostarczanie określonych ilościowo danych wynikających z badań empirycznych.

$\mathrm{Na}$ tle kształtującej się metodologii geografii społeczno-gospodarczej można przyjąć, iż głównym problemem geografii przemysłu są przemiany funkcjonowania i kształtowania się struktury przestrzennej przemysłu w różnych skalach układów przestrzennych, od skali lokalnej, poprzez krajową po skalę światową, w powiązaniu z całokształtem działalności człowieka i uwarunkowań przyrodniczych. Zakładamy, że podstawowym zadaniem teorii wypracowywanej na gruncie geografii przemysłu jest wyjaśnianie wybranych faktów występujących w strukturze przestrzennej przemysłu, przewidywanie ich zmian dokonujących się pod wpływem różnorodnych i zmieniających swoje nasilenie czynników, a także przewidywanie możliwości pojawienia się nowych w wyniku zmieniających się uwarunkowań. Teoria przestrzeni geograficznej, a także struktury przestrzennej przemysłu powinna zmierzać do:

- kodyfikacji istniejącej wiedzy,

- dostarczania bardziej ogólnych hipotez badawczych,

- stopniowego rozszerzania zakresu prawidłowości wynikających z weryfikacji bardziej szczegółowych hipotez badawczych,

- prezentacji wyników badań empirycznych, jako szczególnych przypadków występujących w określonych warunkach oraz związania ich w system bardziej ogólnych prawidłowości, 
- kumulacji wyników badawczych i określania ich struktury,

- dokonywania powiązań między fragmentarycznymi wynikami badań rozproszonymi w literaturze przedmiotu,

- określania i dostarczania wskazówek do dalszych badań, ułatwiających selekcję zagadnień oraz dostarczanych hipotez, które winny być stawiane i poddawane sprawdzaniu w dalszych badaniach empirycznych i rozważaniach teoretycznych,

- ułatwiania kontroli błędnych obserwacji i interpretacji prawidłowości przestrzennych oraz ich hipotez, wskazując na ogólny kontekst czy specyficzne uwarunkowania, w których poszczególne obserwacje i prawidłowości występują.

Ilościowe określenie występowania prawidłowości w strukturze przestrzennej przemysłu powinno dostarczać nowych informacji o danym zjawisku czy dokonującym się procesie oraz pozwalać na przewidywanie przebiegu danego procesu w przyszłości, jego oceny z punktu widzenia założonych celów, budowy odpowiednich modeli funkcjonalnych, a następnie modeli dynamicznych. Należy przyjąć, że im precyzyjniej poznamy relacje ilościowo-jakościowe kształtujące dane zjawiska, tym efektywniej możemy wykorzystać prawidłowości jego kształtowania w odniesieniu do zjawisk ekonomicznych, społecznych i przyrodniczych. Ważnym zagadnieniem jest także określenie, czy proces przemian struktury przestrzennej przemysłu zmierza w racjonalnym kierunku zgodnym z dalszymi celami przemian struktur przestrzenno-sektorowych oraz określenie instrumentów sterowania dalszymi przemianami².

Podstawowym celem geografii przemysłu winno być odkrywanie prawidłowości występujących w strukturze przestrzennej przemysłu, które będą podstawą budowy odpowiedniej teorii. Zakładamy, że zbudowana teoria posłuży właściwemu wyjaśnianiu występujących zjawisk sektorowych, przestrzennych czy sektorowo-przestrzennych, określeniu tendencji przemian oraz ich ocenie z punktu widzenia założonych celów. Umożliwi to podejmowanie określonych decyzji kształtowania danego procesu w przyszłości, zgodnie z przyjętymi celami rozwoju. Nawiązuje to do znanej tezy, że dane zjawisko należy wpierw poznać, by móc poprawnie przewidywać jego dalszy proces przemian, co oznacza, że bez właściwego poznania nie można właściwie przewidywać.

W nawiązaniu do reguł procesu masowego należy nadmienić, że prawidłowości występujące w strukturze przestrzennej przemysłu przejawiają się w dużej ilości zdarzeń. Jeżeli weźmiemy pod uwagę tylko pojedynczy przypadek oddzielnie, to trudno je określić, ponieważ może rządzić nim przypadek. Dopiero w dużej ilości zdarzeń możemy zaobserwować, opisać i wyjaśnić prawidłowości. Pozwala to na budowanie racjonalnych sądów oraz ocen kształtowania się danego zjawiska w strukturze przestrzennej przemysłu, w odniesieniu do założonych oczekiwań.

Prawidłowości występujące w strukturze przestrzennej przemysłu kształtują się pod wpływem bardzo wielu różnorodnych przyczyn, które pobudzają dany proces, utrzymują go na stałym poziomie bądź prowadzą do jego recesji. Mają one charakter obiektywny, niezależnie od tego, czy zostały one opisane i wyjaśnione czy jeszcze nie. Warunkują one regularność i powtarzalność kształtowania się różnorodnych zjawisk i tendencji przemian zjawisk występujących w strukturze przestrzennej przemysłu.

Generalnie prawidłowości określają związki zachodzące między przyczynami i skutkami, które możemy rozpatrywać w określonej przestrzeni, w określonym czasie czy w określonej czasoprzestrzeni. Wskazują one, iż po pewnym określonym zdarzeniu (działa-

${ }^{2}$ Wyłania się stąd konieczność traktowania geografii jako nauki zajmującej się kształtowaniem przestrzeni geograficznej, która jest funkcją elementów przestrzeni przyrodniczej, społeczno-gospodarczej i kulturowej. 
niu, czynności) w układzie przestrzennym następują zawsze określone zdarzenia, przy czym następstwo zaznacza się w określonym czasie. Prawidłowości te mogą występować w postaci określonej współzależności, które możemy określić ilościowo przy pomocy odpowiednio dopasowanej funkcji matematycznej, lub w powtarzających się relacjach współwystępowania w przestrzeni.

Zgodnie z regułami procesu stochastycznego przyjmujemy, że na proces kształtowania struktury przestrzennej przemysłu wpływają czynniki główne (typowe) i czynniki uboczne (losowe, przypadkowe, nietypowe, indywidualne). Działają one na określone zjawiska kształtujące się w strukturze przestrzennej przemysłu często w sposób odmienny.

Przyczyny główne:

- działają na każde zjawisko w sposób jednakowy,

- mają charakter wewnętrzny (ich źródłem są czynniki wewnętrzne),

- ich istota wypływa z charakteru danego zjawiska,

- działają w ściśle określonym kierunku,

- są wspólne dla wszystkich jednostek badanej zbiorowości statystycznej,

- kształtują strukturę (stan) procesu masowego, jego rozwój, zależności zjawisk.

- wywołują prawidłowości w procesach masowych.

Gdyby w strukturze przestrzennej przemysłu działały wyłącznie przyczyny główne, prawidłowości byłyby absolutne - można by je było wyjaśnić przy pomocy funkcji matematycznych.

Przyczyny uboczne:

- działają na każde zjawisko w sposób odmienny,

- mają charakter zewnętrzny (ich źródłem są czynniki zewnętrzne),

- nie są związane $\mathrm{z}$ istotą danego zjawiska,

- działają w różnym kierunku, zakłócając wpływ przyczyn głównych,

- są odmienne dla poszczególnych jednostek badanej zbiorowości statystycznej,

- zakłócają strukturę procesu masowego,

- zakłócają prawidłowości występujące w procesach masowych,

Gdyby w strukturze przestrzennej przemysłu działały jedynie przyczyny uboczne, nie istniałaby żadna prawidłowość, wyłącznie chaos.

W procesie przemian struktury przestrzennej przemysłu zarówno czynniki główne, jak i uboczne działają równocześnie i we wzajemnym powiązaniu. W procesie sterowania procesami przemian dokonującymi się w przestrzeni przemysłowej, w określonych uwarunkowaniach, czynniki główne mają charakter obiektywny i kształtują określone prawidłowości, natomiast przyczyny uboczne je zakłócają i w procesie zarządzania można wpływać na ograniczanie ich negatywnych skutków. Zmiany czynników głównych można dokonać dopiero w drodze zmian uwarunkowań występujących w strukturze przestrzennej przemysłu. Zmiany te mogą wygenerować inny rodzaj czynników głównych, które będą wpływać na kształtowanie się pożądanych przez nas prawidłowości.

W analizie struktury przestrzennej przemysłu ważnym zagadnieniem jest określenie jej jednostek elementarnych. W wyniku wielu badań empirycznych za podstawowe jednostki należy przyjąć przedsiębiorstwa przemysłowe (w wypadku przedsiębiorstw wielozakładowych mogą to być także ich zakłady produkcyjno-usługowe, oddziały czy filie). Lokalizacja zakładów przemysłowych i kształtowanie ich produkcji (wielkości i asortymentu) wynikają z określonych potrzeb rynku (międzynarodowego, krajowego, regionalnego, lokalnego), z miejscowych zasobów (pracy, surowców, dostępu do źródeł energii) i określonej polityki 
przestrzennej państwa. Generalnie wynikają one z dążenia do maksymalizacji zysku poprzez podniesienie efektywności produkcji i konkurencyjności danych produktów (Fierla 1987, Fierla, Kuciński 1994).

Zakłady przemysłowe rozwijają się nie jako odizolowane elementy w przestrzeni geograficznej czy strukturze przestrzennej przemysłu, ale w określonych relacjach z otoczeniem poprzez więzi pasywne, które w wyniku procesu produkcyjnego (transformacji techniczno-ekonomicznej) wytwarzają określone więzi aktywne (rynkowe). Ich funkcjonowanie należy więc rozpatrywać w konwencji układu przyczynowo-skutkowego.

Powiązania zakładu z otoczeniem dokonują się w określonym czasie i przestrzeni. W procesie ich wyjaśniania można wyróżnić cztery warianty:

- znamy przyczyny i znamy skutki,

- znamy przyczyny, a nie znamy skutków,

- nie znamy przyczyn, a znamy skutki,

- nie znamy przyczyn i nie znamy skutków.

W pierwszym wariancie znamy przyczyny (relacje pasywne) i znamy skutki (relacje aktywne) oraz wynikające z nich prawidłowości. W praktyce podejmując określone działania wiemy, jakie będą ich konsekwencje.

W drugim wariancie znamy przyczyny (działania), ale do końca nie znamy ich skutków (np. sytuacja na światowym rynku paliw, zmieniająca się pozycja oferowanego produktu na konkurencyjnym rynku). Podejmujemy określone działania (decyzje), ale nie wiemy do końca, jakie będą ich efekty (np. ekonomiczne, społeczne, kulturowe czy polityczne). Ważnym problemem jest tu dążenie do określania minimum ryzyka oraz próby przewidywania prawidłowości odnoszących się do skutków.

W trzecim wariancie znamy skutki, ale do końca nie znamy ich przyczyn (np. kryzysów gospodarczych, recesji światowych korporacji, wahań rynkowych określonych produktów, pogłębiania rynku). Skutki te mogą być pozytywne, obojętne lub negatywne. W takiej sytuacji zachodzi konieczność ustalania prawidłowości odnoszących się do przyczyn.

W czwartym wariancie nie znamy przyczyn i nie znamy skutków, wówczas nie wiemy lub nie zdajemy sobie sprawy, że zachodzi jakieś oddziaływanie na dany element przestrzeni przemysłowej (odnosi się to zwłaszcza do małych firm osób fizycznych, które po powstaniu nie zawsze mają szanse na rozwój swojej działalności i w konsekwencji często upadaja).

Proces przemian zakładu przemysłowego przejawia się więc w jego wzroście, stagnacji, recesji czy zaniku. Uzależniony jest on od natężenia działania impulsów płynących z otoczenia (zaopatrzenia surowcowego, kooperacji, konkurencyjności produktów na rynku, w skali lokalnej, regionalnej, krajowej, światowej) i wewnętrznej elastyczności, czyli zdolności dostosowania się do tych zewnętrznych impulsów (np. poprzez zdolności do podniesienia konkurencyjności, zmiany profilu produkcji, technicznej modernizacji procesu produkcyjnego).

Zakłady przemysłowe jako elementy struktury przestrzennej przemysłu nie stanowią jednorodnych elementów, ale odznaczają się dużym zróżnicowaniem pod względem: potencjału kapitałowego, produkcyjnego, przynależności do określonych rodzajów wytwórczości (asortymentu produkcji), funkcji spełnianych w przestrzeni gospodarczej, zasięgu powiązań rynkowych, a także miejsc ich lokalizacji. Ze względu na przestrzenny zasięg powiązań pasywnych i aktywnych zakładu możemy wyróżnić zakłady o funkcjach: lokalnych, ponadlokalnych, regionalnych, ponadregionalnych, krajowych czy międzynarodowych i światowych (globalnych).

Przemiany zakładów przemysłowych w strukturze przestrzennej przemysłu nawiązują do prawa koncentracji kapitału. Przejawia się ono w wykształcaniu się coraz potężniejszych 
pod względem kapitału korporacji światowych, które swoim zasięgiem oddziaływania obejmują często przestrzeń światową oraz wykazują tendencje do koncentracji przestrzennej ich zarządów i zakładów produkcyjno-usługowych. Zróżnicowane zakłady pod względem potencjału i spełnianych funkcji w strukturze przestrzennej wraz z ich wzajemnymi powiązaniami (relacjami) tworzą bardziej złożone przestrzenne układy przestrzenne, reprezentowane przez określone formy koncentracji przemysłu, takie jak: skupienia, ośrodki, okręgi, kompleksy przemysłowe czy obszary o różnym stopniu uprzemysłowienia.

W tej konwencji należy przyjąć, że struktura przestrzenna przemysłu jest systemem, który tworzy zbiór różnego rodzaju zakładów przemysłowych oraz tworzących je przestrzennych form koncentracji przemysłu wraz z relacjami zachodzącymi między nimi. System ten jest także powiązany z otoczeniem (reprezentowanym przez pozostałe elementy przestrzeni geograficznej) za pomocą różnego typu powiązań pasywnych i aktywnych. Interakcje otoczenia z danym przestrzennym układem przemysłowym mogą odznaczać się różną wielkością i różnym nasileniem i mogą wpływać na zmianę uwarunkowań kształtowania struktury przemysłowej oraz utrwalanie, osłabianie czy pojawianie się nowych prawidłowości.

W strukturze przestrzennej przemysłu występują prawidłowości odnoszące się do kształtowania firm, zespołów firm tej samej lub różnych branż, określonych form koncentracji przemysłu, występujących na określonych obszarach. Oznacza to, że struktury przestrzennej przemysłu nie można traktować jako sumy przedsiębiorstw, ale jako ich funkcję. Funkcja bowiem jest czymś więcej niż sumą elementów, zawiera dodatkowo relacje (powiązania) występujące między zakładami czy przestrzennymi układami przemysłowymi. W konsekwencji prawidłowości odnoszące się do przestrzeni przemysłowej jako całości nie muszą być prawidłowościami odnoszącymi się do określonych form koncentracji przemysłu, a także do poszczególnych zakładów.

Przestrzenne formy koncentracji przemysłu wykształcone w strukturze przestrzennej przemysłu w procesie przemian wykazują różne tendencje przemian, które przejawiają się w ich rozkładzie i rozrastaniu lub integracji.

1. Proces rozkładu danego przemysłowego układu przemysłowego przejawia się m.in. w systematycznym obniżaniu konkurencyjności zakładów. W konsekwencji stają się one coraz mniej efektywne i coraz bardziej ograniczają swoje funkcje w układzie rynkowym. Proces ten może charakteryzować się różnym stopniem nasilenia, ale nie można go zatrzymać ani zmienić jego kierunku (zużycie maszyn, starzenie produktów, upadek form gospodarowania, zmiany systemów politycznych).

2. Rozrastanie się przestrzennych form koncentracji przemysłu dokonuje się dzięki procesowi osłabiania wewnętrznej spójności między poszczególnymi zakładami. Prowadzi to do stopniowego usamodzielniania się i tworzenia nowych samodzielnych jednostek produkcyjnych oraz do wykreowania nowych funkcji. Proces ten, w stosunku do rozkładu, polega na tworzeniu czegoś nowego w strukturze starego systemu, np. nowych jednostek organizacyjnych i produkcyjno-usługowych w wyniku stopniowego usamodzielniania się firm występujących w strukturze dużej korporacji. Polega on na stopniowym osłabianiu początkowego stanu spójności zarządzania i organizacji do stanu wykształcania się samodzielnych nowych przedsiębiorstw.

3. W przeciwieństwie do procesu rozkładu czy rozrastania może nastąpić proces integracji przemysłu, który charakteryzuje się: wzmacnianiem już istniejących powiązań między zakładami i rynkami, zwiększaniem liczby powiązań pasywnych i aktywnych, włączaniem do istniejącej struktury organizacyjnej nowych przedsiębiorstw (przejęcia, konsolidacja, zakup) oraz wykształcaniem się nowych powiązań funkcjonalnych. Prowadzi to do wzrostu 
spójności przestrzennego układu przemysłowego, który dąży do zwiększania sprawności i funkcjonalności poszczególnych przedsiębiorstw, zakładów czy filii (np. przejmowanie przedsiębiorstw krajowych przez korporacje międzynarodowe).

W procesie tym coraz bardziej wyodrębnia się rola zarządu przedsiębiorstwa (korporacji), który wzmacnia funkcję zarządzającą i odgrywa decydującą rolę w określaniu zasad funkcjonowania, przepływu finansowo-kapitałowego oraz produktów, wytyczania kierunków dalszego rozwoju korporacji jako określonej całości. Natomiast pozostałe zakłady (elementy strukturalne korporacji) wykonują zadane polecenia dotyczące organizacji, produkcji rynku i powiązań przestrzenno-produkcyjnych.

Struktura przestrzenna przemysłu nie kształtuje się samodzielnie, ale wykazuje powiązania z innymi elementami otoczenia. Dlatego ważnym zagadnieniem jest określanie prawidłowości jej funkcjonowania i przemian w relacjach z pozostałymi elementami przestrzeni geograficznej, tj. otoczeniem przyrodniczym, społecznym, ekonomicznym i kulturowym (Zioło 1997, 1999).

W procesie przemian, w zależności od zmieniających się relacji z otoczeniem i uwarunkowań wewnętrznych, poszczególne przestrzenne układy przemysłowe mogą wykazywać różne tendencje przemian (Zioło 1986). W konwencji modelowej możemy przyjąć, że mogą one podlegać przemianom o charakterze ilościowym lub ilościowo-jakościowym³ ${ }^{3}$.

I. Przemiany ilościowe przestrzennych układów przemysłowych (form koncentracji przemysłu, obszarów przemysłowych, jednostek osadniczych) odznaczają się zmianami wielkości potencjału poszczególnych zakładów występujących w ich strukturze. W zależności od nasilenia impulsów oddziałujących na poszczególne zakłady mogą one odznaczać się wzrostem, stagnacją lub recesją (ryc. 1).

1. Proces wzrostu danego układu przemysłowego cechuje się w miarę proporcjonalnym zwiększaniem potencjału ekonomicznego poszczególnych zakładów. W konsekwencji zbliżonego tempa wzrostu poszczególne zakłady utrzymują zbliżony udział w strukturze potencjału danego układu. W wyniku proporcjonalnego zwiększania się potencjału poszczególnych zakładów, w danym układzie przestrzennym nie następują zmiany jego struktury wewnętrznej. Proces ten dokonuje się w podobnych warunkach, które w jednakowym stopniu wpływają na zwiększanie potencjału poszczególnych zakładów.

2. Proces stagnacji następuje w wyniku osłabienia czynników pobudzających wzrost wraz z pojawianiem się pewnych barier hamujących. W konsekwencji poszczególne zakłady odznaczają się stagnacją potencjału, wpływając na jego stabilny poziom oraz stabilną strukturę wewnętrzną. Proces ten z reguły nie utrzymuje się długo i jest zazwyczaj fazą przejściową do innego typu przemian.

3. Proces recesji (regresu) jest wynikiem znacznego osłabienia czy zaniku działania dotychczasowych czynników wzrostu lub pojawienia się znacznie silniejszych barier hamujących aniżeli czynników wzrostu. Bariery te oddziaływają z jednakowym nasileniem na poszczególne elementy danego układu przemysłowego. W konsekwencji poszczególne zakłady proporcjonalnie zmniejszają swój potencjał, co powoduje ogólne zmniejszanie potencjału danego układu. Proces ten jest wynikiem zmiany uwarunkowań ograniczających dotychczasowe tendencje wzrostu, które w jednakowym stopniu wpływają na poszczególne zakłady przemysłowe.

${ }^{3}$ Model jest uproszczonym obrazem rozległej problematyki badawczej, stanowiącej przedmiot badania i poznania w danej dyscyplinie. Jest on teoretycznym uogólnieniem określonego wycinka rzeczywistości, który w sposób syntetyczny i w jakimś stopniu uproszczony stara się odwzorować zachodzące w nim procesy. 

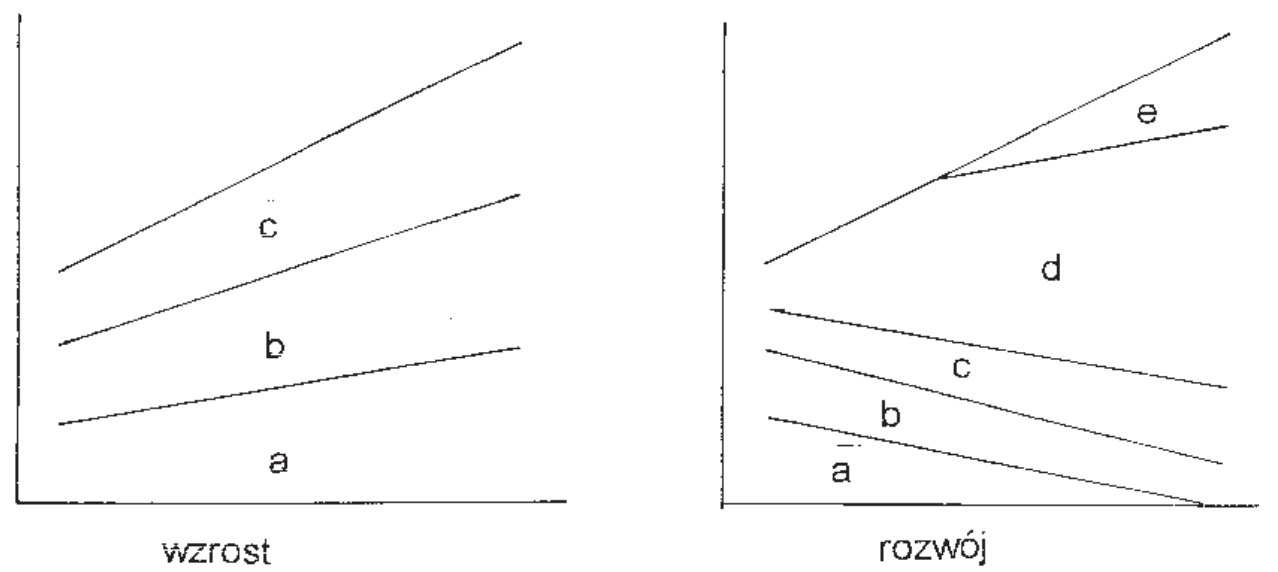

warost

rozwój
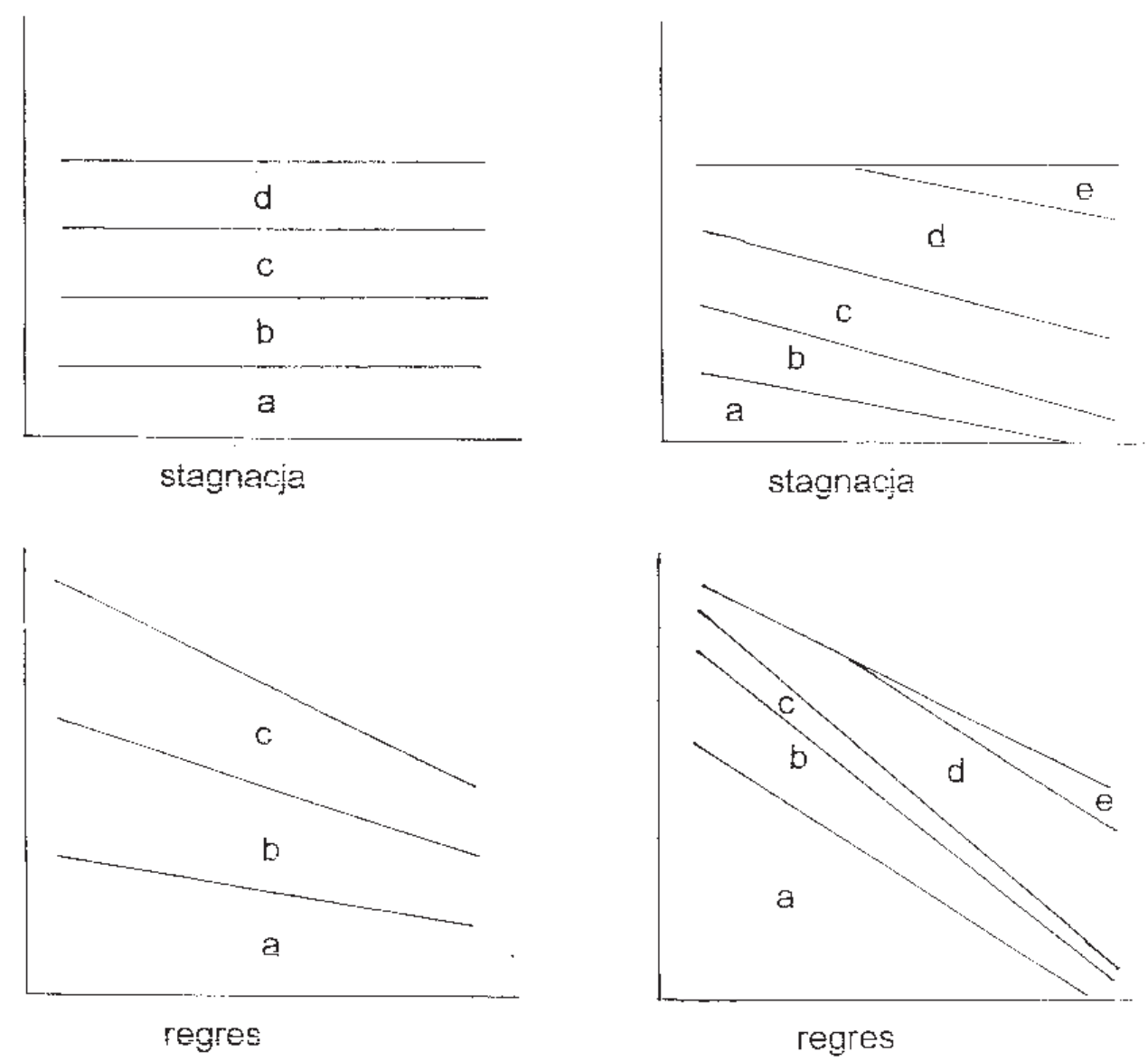

Ryc. 1. Modele przemian struktur społeczno-gospodarczych. Typy zachowań elementów: a) zanikłe, b) zanikające, c) stagnujące, d) rozwijające się, e) nowo pojawiające się 
Omówione procesy charakteryzują się zmianami potencjału przemysłowego poszczególnych zakładów, która prowadzi do stałej struktury wewnętrznej.

II. Przemiany ilościowo-jakościowe odznaczają się zmianami wielkości potencjału poszczególnych zakładów w strukturze danego układu przemysłowego, co prowadzi do zmian ich udziału w jego strukturze. W procesie przemian ilościowo-jakościowych zmieniające się uwarunkowania, a także czynniki i bariery selektywnie działają na poszczególne zakłady przemysłowe, wpływając na zmiany udziału ich potencjału w strukturze danego układu.

1. Proces rozwoju potencjału danego układu przestrzennego dokonuje się w wyniku ogólnego wzrostu jego potencjału, który następuje przy zróżnicowanej dynamice przemian poszczególnych zakładów. Zróżnicowana dynamika potencjału poszczególnych zakładów wywołana jest przez różnorodne czynniki selektywnie oddziaływujące na poszczególne firmy danego układu. Prowadzi to do ilościowo-jakościowych zmian potencjału danego układu przemysłowego, które dokonują się w wyniku zmiany rangi i udziału poszczególnych zakładów w jego strukturze. W procesie rozwoju poszczególne zakłady mogą zachowywać się jako elementy: znikłe, zanikające (recesyjne), stagnujące, rozwijające się oraz elementy nowo pojawiające się.

A. Zakłady zanikłe reprezentowane są przez jednostki, które w zmieniających się uwarunkowaniach i pod wpływem działania określonych czynników nie były w stanie dostosować się do nowych warunków i utraciły swoje funkcje. W konsekwencji w strukturze całości okazują się elementami zbędnymi.

B. Zakłady zanikające (recesyjne) tracą stopniowo swoje znaczenie w strukturze danego układu przestrzennego. W wyniku zmian uwarunkowań nie nadążają one za nowymi wyzwaniami, do których nie są się w stanie w zaistniałych warunkach szybko dostosować.

C. Zakłady stagnujące charakteryzują się zbliżoną dynamiką potencjału do ogólnej dynamiki danego układu przestrzennego przemysłu. Stąd ich względny udział w potencjale danego układu nie ulega zasadniczej zmianie i utrzymuje się na zbliżonym poziomie.

D. Zakłady rozwijające się odznaczają się wyższą dynamiką wzrostu aniżeli pozostałe firmy. W znacznym stopniu nawiązują one do nowych wyzwań wynikających z nowych tendencji rozwojowych. Stopniowo zwiększają swoje znaczenie w ogólnym potencjale danego układu, co prowadzi do zwiększania ich udziału w jego strukturze. W konsekwencji często przejmują dominujące funkcje i tworzą nową jakość bazy produkcyjnej układu przestrzennego.

E. Zakłady nowo pojawiające się reprezentowane są przez nowo zlokalizowane firmy w danym okresie czasu w strukturze danego układu przestrzennego. Ich powstanie nawiązuje do nowych wyzwań wynikających ze społecznego podziału pracy, np. działań na rzecz budowania gospodarki opartej na wiedzy (np. firmy informatyczne). Stopniowo mogą one zwiększać swój udział w ogólnym potencjale, przygotowując się do przejęcia funkcji zakładów rozwijających się.

2. Stagnacja przestrzennego układu przemysłowego w procesie zmian ilościowo-jakościowych przejawia się w niewielkich wahaniach jego ogólnego potencjału przemysłowego, któremu równocześnie towarzyszy zmiana jego struktury. W procesie tym zaznacza się znaczny wpływ czynników ograniczających dalszy jego ogólny wzrost potencjału. Czynniki te selektywnie oddziaływają na zachowania poszczególnych zakładów. W konsekwencji w strukturze danego układu mogą występować - podobnie jak w poprzednich wariantach zakłady: zanikłe, zanikające, stagnujące, rozwijające się, a także nowo pojawiające się.

3. Proces regresji w warunkach zmian ilościowo-jakościowych wynika z silnie działających barier hamujących. Przejawia się on w ogólnej recesji danego układu przemysło- 
wego, która prowadzi do zmniejszania jego ogólnego potencjału. Bariery hamujące wzrost poszczególnych zakładów odziaływują z różnym natężeniem powodując, jak w poprzedniej sytuacji, ich odmienne zachowania. W konsekwencji w strukturze danego układu zaznaczają się poważne zmiany, a poszczególne zakłady mogą zachowywać się jako: zanikłe, zanikające, stagnujące, rozwijające się i nowo pojawiające się.

Zaletą przedstawionego modelu przemian przestrzennych układów przemysłowych jest fakt, że uwzględnia on wszystkie możliwe warianty przemian, z jakimi możemy się spotkać w badaniach empirycznych. W dłuższym okresie czasu w zależności od zmieniających się uwarunkowań oraz zróżnicowanego stopnia nasilenia działania określonych czynników oraz pojawiania się nowych czy zmieniającego się nasilenia barier w przemianach danego układu przestrzennego mogą występować tendencje nawiązujące do różnych wariantów przemian ilościowych, a także przemian ilościowo-jakościowych.

Przedstawiony model wariantów zachowań przestrzennych układów przemysłowych może być wykorzystany jako narzędzie badania procesów transformacji różnej skali przestrzennych układów przemysłowych. Wykorzystując trendy liniowe, możemy określić dalsze tendencje zachowań danego układu jego struktury wewnętrznej, a także tendencje zachowań poszczególnych zakładów. Nawiązujemy tu do założenia, że zadaniem teorii struktury przestrzennej przemysłu jest ocena dotychczasowej wiedzy oraz stworzenie ogólnych wzorców (paradygmatów) w celu prowadzenia badań przestrzennych dotyczących zachowań przedsiębiorstw przemysłowych, poszczególnych branż, przestrzennych form koncentracji przemysłu oraz różnego typu obszarów kształtowanych przez przemysł w ich zmieniającym się otoczeniu światowym, europejskim, krajowym, regionalnym czy lokalnym.

W niniejszych rozważaniach przyjmujemy, że przedmiotem badań geografii przemysłu są powiązania zachodzące między przedsiębiorstwami (zakładami) jako elementami przestrzeni przemysłowej, a także ich relacje z pozostałymi elementami przestrzeni geograficznej. W badaniach tych szczególne znaczenie mają relacje (Domański 1982):

- współwystępowania,

- równokształtności,

- stopniowania,

- następstwa w czasie,

- przejściowości,

- trwałości (przetrwałości),

- między funkcją a formą,

- wzajemnej zależności,

- między częściami (elementami, podzbiorami) zbioru,

- między częściami a całością (elementu, podzbioru).

W procesie poznawczym należy starać się odpowiadać na pytania:

- co to jest? (fakty, opis),

- co jest jakie? (właściwości),

- jak to powstało? (wyjaśnienie kształtowania się procesu, impulsy pobudzające, zmienność uwarunkowań, czynniki sterujące, zmiany struktury),

- co od czego zależy? (nasilenie powiązań czy relacji),

- jak kształtować wewnętrzną zgodność struktury i relacje zewnętrzne? (optymalizacja wynikająca np. z rachunku ekonomicznego czy negocjacji),

- jak będzie się kształtować w przyszłości? (prognoza na podstawie dotychczasowych uwarunkowań oraz przewidywanych zmian uwarunkowań i czynników), 
- czy będzie się racjonalnie kształtować? (ocena prognozy z punktu widzenia założonych celów),

- jakie są cele kształtowania na przyszłość? (wybór celów wynikających z uwarunkowań oraz bliższych i dalszych tendencji rozwojowych),

- jak powinno się racjonalnie kształtować? (dobór instrumentów sterujących),

- monitoring (obserwacja, czy proces rozwija się zgodnie z założonymi celami),

- weryfikacja dokonujących się zmian w drodze korygowania instrumentów sterujących.

Reasumując należy stwierdzić, iż podejmując problematykę budowy teorii przestrzeni przemysłowej (geografii przemysłu) trzeba uwzględnić następujące wstępne założenia (Zioło 2007):

- Proces kształtowania się przestrzeni geograficznej dokonuje się pod wpływem nakładania się praw: megaekonomicznych (odnoszących się do przestrzeni światowej, kontynentów), makroekonomicznych (gospodarka krajowa), mezoekonomicznych (sektory gospodarki, gospodarka regionalna, różne skale przestrzennych układów przemysłowych) i mikroekonomicznych (przedsiębiorstw przemysłowych, usługowych, innych podmiotów gospodarczych i instytucji), które w swojej istocie mają charakter aprzestrzenny, na zróżnicowane uwarunkowania określonej skali układów przestrzennych (od skali światowej poprzez skale kontynentów, grup państw, poszczególnych krajów, układów ponadregionalnych, po układy regionalne, subregionalne, ponadlokalne i lokalne).

- Zróżnicowanie przestrzeni geograficznej oraz jej przemiany stwarzają określone (pozytywne, obojętne, negatywne) uwarunkowania dla kształtowania się procesu rozwoju społecznego, gospodarczego i kulturowego, które są wyrazem stopnia jej atrakcyjności dla kształtowania procesów ekonomicznych.

- Przedmiotem badań poszczególnych nauk geograficznych są wybrane elementy przestrzeni, określane poprzez przyjęty cel, który jest realizowany przy pomocy odpowiednio wypracowanych metod badawczych.

- Geografia przemysłu jest jedną z nauk geograficznych, jej przedmiotem badań jest kształtowanie się struktury przestrzennej przemysłu oraz określonych przestrzennych układów przemysłowych; nawiązuje ona do ogólnego procesu kształtowania się pozostałych nauk, które znajdują się na różnym etapie rozwoju metodologicznego.

- Podstawowymi elementami przestrzeni przemysłowej są zróżnicowane pod względem potencjału i branży oraz spełnianych funkcji w gospodarce przedsiębiorstwa przemysłowe, zakłady, filie czy przedstawicielstwa firm.

- Proces kształtowania się przestrzeni geograficznej, w tym struktury przestrzennej przemysłu, nawiązuje do zmieniających się uwarunkowań wynikających z postępu cywilizacyjnego i przechodzenia do informacyjnej fazy rozwoju, który przejawia się m.in. w systematycznej modernizacji działalności produkcyjnej i usługowej, poprzez postępujące procesy mechanizacji, automatyzacji i robotyzacji.

- W procesie rozwoju zmienia się rola przemysłu jako elementu struktury społeczno-gospodarczej różnej skali układów przestrzennych, np. w zakresie jego udziału w strukturze wartości PKB, spadku znaczenia jako rynku pracy i in.

- Zróżnicowanie przestrzeni geograficznej, w tym przemysłowej sprawia, iż występują w jej strukturze różne uwarunkowania dla kształtowania się określonych rodzajów działalności przemysłowej (zanik tradycyjnych produktów oraz pojawianie się nowych, np. firm informatycznych). 
- Proces kształtowania się działalności przemysłu jest wynikiem procesów ekonomicznych oraz postępującego rozwoju technologicznego i technicznego produkcji, w których jako podstawowe kryterium podejmowania działalności przyjmuje się dążenie do maksymalizacji efektów ekonomicznych; temu celowi służą podejmowane decyzje dotyczące:

- rozwijania potencjału dotychczasowych lokalizacji działalności produkcyjnej, produkcyjno-usługowej, usługowej, badawczo-rozwojowej i in., a także likwidowania istniejących lokalizacji (miejsc działalności) czy poszukiwania nowych lokalizacji,

- zwiększania rozmiarów i kierunków modernizacji istniejącej produkcji oraz wdrażania unowocześnianych czy nowych produktów,

- podejmowania określonych zmian organizacyjnych w zakresie pionowego i poziomego zarządzania działalnością przedsiębiorstwa oraz przekazywania określonych kompetencji na różne szczeble zarządzania czy do różnych oddziałów produkcyjnych,

- rozwijania istniejących i podejmowania poszukiwań nowych źródeł zasilania kapitałowego i finansowego czy energetycznego,

- kierunków działań marketingowych w zakresie: utrzymania, pogłębiania czy rozszerzania rynków zbytu produktów gotowych, powiązań surowcowych, kooperacyjnych $\mathrm{i}$ in.

- Nasilająca się konkurencja między producentami wpływa na postępujący proces koncentracji kapitału, w wyniku którego następuje integracja przedsiębiorstw przemysłowych w drodze: przejęć, konsolidacji, zakupu, co prowadzi do pojawiania się coraz większych organizacji przemysłowych, występujących obecnie w formie coraz potężniejszych korporacji przemysłowych o charakterze międzynarodowym czy globalnym.

- Przedsiębiorstwa przemysłowe w przestrzeni społeczno-gospodarczej tworzą określone powiązania sieciowe poprzez fakt, iż są one miejscem skupiania się więzi pasywnych (wyznaczanych przez miejsca zaopatrzenia) oraz więzi aktywnych (w zakresie powiązań rynkowych z innymi przedsiębiorstwami, sektorami gospodarczymi czy określonymi obszarami), które wyrażają przepływy między różnymi zakładami, gałęziami, między gałęziami a określonymi układami przestrzennymi, między określonymi układami a gałęziami.

- W kształtowaniu struktury przestrzennej podstawową rolę odgrywają procesy koncentracji (nawiązujące do ogólniejszych procesów polaryzacji) oraz procesy decentralizacji (dążące do wyrównywania dysproporcji w zakresie uprzemysłowienia i rozpraszania działalności produkcyjnej):

- nasilające się procesy koncentracji przestrzennej przemysłu prowadzą do wykształcania się coraz bardziej złożonych przestrzennych form koncentracji (zespoły przemysłowe, ośrodki i okręgi oraz kompleksy przemysłowe, a także technopolie, parki technologiczne czy klastry-grona) lub różnego typu obszarów przemysłowych czy uprzemysłowionych,

- nasilające się procesy decentralizacji prowadzą do rozpraszania przestrzennego działalności produkcyjnej.

- Procesy przemian struktury przestrzennej przemysłu (przestrzennych form koncentracji przemysłu, obszarów uprzemysłowionych, przemysłu rozproszonego) dokonują się w wyniku zmian w procesie kształtowania się poszczególnych przedsiębiorstw 
(zakładów) przemysłowych, które mogą się zachowywać jako elementy: zanikłe, zanikające, stagnujące, rozwijające się, nowo pojawiające się.

- Zróżnicowane pod względem potencjału produkcyjnego, rodzajów działalności gospodarczej i zasięgu powiązań przestrzennych przedsiębiorstwa przemysłowe spełniają w strukturze przestrzennej przemysłu różne funkcje: wiodące, komplementarne (pojawiające się w wyniku rozwoju zakładów wiodących), standardowe, lokalne.

- W procesie przemian cywilizacyjnych przejawiających się $\mathrm{w}$ przechodzeniu $\mathrm{z}$ fazy industrialnej do postindustrialnej, a następnie fazy informacyjnej zmienia się funkcja przemysłu w strukturze bazy ekonomicznej pod względem rozmiarów rynku pracy oraz udziału w dochodzie narodowym czy obrotach międzynarodowych.

- Przemysł jest jednym z ważniejszych sektorów gospodarczych w zakresie przyciągania endogenicznych czynników rozwoju społeczno-gospodarczego (np. w postaci bezpośrednich inwestycji zagranicznych).

- Egzogeniczne czynniki rozwoju danej skali układów przestrzennych (np. kapitał) związane są najczęściej z poszukiwaniem nowych miejsc lokalizacji czy powiązań produkcyjnych, wybierają obszary o znaczącej sile przyciągania wynikającej z określonego poziomu ich konkurencyjności.

- Kształtowanie się przedsiębiorstwa przemysłowego, różnych form koncentracji przemysłu i obszarów przemysłowych jest procesem dynamicznym, na który wpływają impulsy płynące $\mathrm{z}$ otoczenia (innych przedsiębiorstw przemysłowych, pozaprzemysłowych podmiotów gospodarczych i instytucji) oraz z uwarunkowań wewnętrznych.

- Podobnie kształtowanie się różnych form koncentracji przemysłu i obszarów przemysłowych jest procesem dynamicznym, na który wpływają impulsy płynące z różnej skali otoczenia, czynniki wygenerowane przez uwarunkowania wewnętrzne, a także wielkość i nasilenie powiązań lokalnych zaznaczających się między występującymi już na ich terenie przedsiębiorstwami.

Zarysowana problematyka badawcza struktury przestrzennej przemysłu nie wyczerpuje wszystkich zagadnień istotnych dla rozwoju teorii i studiów empirycznych podejmowanych na polu geografii przemysłu. Dalszy jej rozwój winien zmierzać nie tylko do wyjaśniania i ocen zróżnicowań występujących w strukturze przestrzennej przemysłu, ale także do zaproponowania racjonalnych kierunków jej dalszych przekształceń. Wydaje się, że przyjęcie tego kierunku podniesie pozycję konkurencyjną geografii przemysłu w stosunku do innych nauk i pozwoli na realizację celów aplikacyjnych.

Sygnalizując wybrane zagadnienia zdajemy sobie sprawę, iż zaprezentowana koncepcja wymaga coraz ściślejszych definicji, rozwijania koncepcji badawczych w nawiązaniu do teorii systemów dynamicznych oraz egzemplifikacji ujęć teoretycznych w coraz bardziej pogłębianych badaniach empirycznych. Zrealizuje się w ten sposób budowanie cząstkowych teorii geografii przemysłu, a następnie stopniowe wypełnianie luk w wypracowanej teorii oraz zastosowanie jej w badaniach empirycznych podporządkowanych analizie i ocenie dotychczasowych procesów rozwoju oraz współczesnych struktur, które mogą stanowić przesłankę do podejmowania określonych decyzji. 


\section{Literatura}

Beer S. 1966, Cybernetyka a zarzqdzanie, PWN, Warszawa

Chojnicki Z. 1970, Podstawowe tendencje metodologiczne wspótczesnej geografii ekonomicznej, „Przegląd Geograficzny”, z. 2

Chojnicki Z. 1973, Założenia i perspektywy rozwojowe geografii ekonomicznej, „Przegląd Geograficzny", z. 1

Chojnicki Z. 1980, Podstawy prognozowania regionalnych systemów osadniczych, „Przegląd Geograficzny", z. 4

Chojnicki Z. (red.), 2004, Geografia wobec problemów teraźniejszości i przyszłości, Wyd. Nauk. Bogucki, Poznań

Chojnicki Z., Dziewoński K. 1978, Podstawowe zagadnienia metodologiczne geografii ekonomicznej, „Przegląd Geograficzny”, z. 2

Dobrowolska M. 1965, Tendencje rozwojowe geografii przemystu w okresie XX-lecia Polski Ludowej, „Przegląd Geograficzny”, z. 4

Domański R. 1967, Konstruowanie teorii w geografii ekonomicznej, „Przegląd Geograficzny”, z. 1

Domański R.,1982, Teoretyczne podstawy geografii ekonomicznej, PWE, Warszawa

Fierla I. 1987, Lokalizacja przemystu, PWE, Warszawa

Fierla I. 1990, Geografia przemystu Polski, PWE, Warszawa

Fierla I. 1992, Uwarunkowania restrukturyzacji przemystu w największych okręgach przemysłowych w Polsce, Monografie i Opracowania SGPiS, nr 16, Warszawa

Fierla I., Kuciński K. 1994, Systemowe uwarunkowania lokalizacji przemystu w Polsce, Monografie i Opracowania SGPiS, nr 387, Warszawa

Hall A.D. 1968, Podstawy techniki systemów, PWN, Warszawa

Kitowski J. (ed.) 2001, Spatial Dimension of Socio-Economic Transformation Process in Central and Eastern Europe on the turn of the 20-th Century, The Stanisław Leszczycki Institute of Geography and Spatial Organization Polish Academy of Sciences in Warszaw, Faculty of Economics, the Maria Curie-Skłodowska University, Branch Rzeszów, Higher School of Administration and Management in Przemyśl, Commission of Communicational Geography of the Polish Geographical Society in Warsaw, Rzeszów

Kitowski J. (ed.), 2003, Eastern Dimension of European Union, Polish Academy of Sciences, Geopolitical Studies, Institute of Geography and Spatial Organization, Warsaw, vol. 11

Kowalczyk E. 1987, Cybernetyka - myśl porzqdkująca, Wszechnica Akademii Nauk, WrocławWarszawa-Kraków-Gdańsk-Lódź

Kortus B. 1981, Geografia przemystu i jej aktualne problemy badawcze, „Przegląd Geograficzny”, z. 2 Kortus B. 1986, Wstep do geografii przemystu, PWN, Warszawa

Leszczycki S., Kukliński A. 1964, Perspektywy rozwoju geografii przemystu w Polsce, „Przegląd Geograficzny", z. 2

Łoboda J. 2004, Stan i perspektywy polskiej geografii w opinii geografów, „Przegląd Geograficzny”, z. 4

Mynarski S. 1974, Elementy teorii systemów i cybernetyki, PWN, Warszawa

Misztal S., Zioło Z. (red.), 1998, Dorobek polskiej geografii przemystu, Polskie Towarzystwo Geograficzne, Komisja Geografii Przemysłu, Instytut Geografii Wyższej Szkoły Pedagogicznej im. Komisji Edukacji Narodowej w Krakowie, Wyd. Krakowskiego Oddziału PAN, WarszawaKraków

Pakuła L. 1983, Próba oceny regionalnych badań przemystu, Folia Geographica, Series Geographica-Oeconomica, vol. 15

Szymański J.M. 1991, Życie systemów, Wiedza Powszechna, Warszawa

Ziemba S., Jarominek W., Staniszewski R. 1980, Problemy teorii systemów, Wszechnica Akademii Nauk, Wrocław-Warszawa-Kraków-Gdańsk-Lódź 
Zioło Z. (red.), 1986, Rozwój przemystu i przemiany struktury przestrzenno-gałęziowej województwa bielskiego w latach 1975-1985, WUS, Bielsko-Biała

Zioło Z. 1971, Stan badań nad problemem struktury przestrzennej przemystu i jej form koncentracji, Materiały informacyjne WKPG w Rzeszowie, Rzeszów

Zioło Z. 1978, Próba konstrukcji teoretycznego modelu okręu przemysłowego, [w:] Przemiany społeczno-ekonomiczne Tarnobrzeskiego Rejonu Uprzemysławianego, red. Z. Zioło, PWN, Warszawa

Zioło Z. 1980, Wplyw przemystu na rozwój społeczno-ekonomiczny regionu rzeszowskiego, PWN, Warszawa

Zioło Z. 1986, Model przemian struktur przemysłowych, [w:] Rozwój przemystu i przemiany struktury przestrzenno-gatęziowej województwa bielskiego w latach 1975-1986, red. Z. Zioło, WUS, Bielsko-Bała

Zioło Z. 1987, Próba zarysu teorii struktury przestrzennej przemystu, Rocznik Naukowo-Dydaktyczny WSP w Krakowie, z. 112, Prace Geograficzne XI, Wyd. Nauk. WSP, Kraków

Zioło Z. (red.), 1988, Zakład przemysłowy w akademickim kształceniu nauczycieli, Materiały i Sprawozdania nr 16, COMSN, Wyd. Nauk. WSP, Kraków

Zioło Z. (red.), 1990, Problematyka ośrodka przemysłowego w akademickim kształceniu nauczycieli geografii, Materiały i Sprawozdania nr 19, COMSN, Wyd. Nauk. WSP, Kraków

Zioło Z. (red.), 1993, Problematyka okregu przemysłowego $w$ akademickim ksztatceniu nauczycieli geografii, Materiały i Sprawozdania nr 26, COMSN, Komisja Geografii Przemysłu PTG, Wyd. Nauk. WSP, Kraków

Zioło Z. 1997, Miejsce struktury przestrzennej w przestrzeni geograficznej, [w:] Geografia, Człowiek, Gospodarka. Ksiega dedykowana profesorowi Bronisławowi Kortusowi w 70. rocznicę urodzin, Kraków

Zioło Z. 1999, Model funkcjonowania przestrzeni geograficznej jako próba integracji badań geograficznych, [w:] Geografia na przetomie wieków - jedność w różnorodności, Wydział Geografii i Studiów Regionalnych Uniwersytetu Warszawskiego, Warszawa

Zioło Z. (red.), 2001, Problemy przemian struktur przemysłowych w procesie wdrażania regut gospodarki rynkowej, Prace Komisji Geografii Przemysłu PTG, nr 3, Warszawa-Kraków-Rzeszów

Zioło Z., Makieła Z. (red.), 2003, Kształtowanie się struktur przemysłowych, Prace Komisji Geografii Przemysłu nr 5, Warszawa-Kraków

Zioło Z., Rachwał T. (red.), 2006, Międzynarodowe uwarunkowania rozwoju polskiego przemystu, Prace Komisji Geografii Przemysłu PTG nr 8, Warszawa-Kraków

Zioło Z. 2007, Zarys koncepcji budowy teorii struktury przestrzennej przemystu, [w:] Problematyka XII Ogólnopolskiej Konferencji Naukowej nt. Problemy metodologiczne geografii przemystu, red. Z.Zioło, M. Borowiec, Komisja Geografii Przemysłu PTG w Warszawie, Zakład Przedsiębiorczości i Gospodarki Przestrzennej Instytutu Geografii Akademii Pedagogicznej w Krakowie, WarszawaKraków, s. 14-20

\section{Industrial spatial structure: research problems}

In the development of every field of science, we observe a sequence of stages connected with more and more precise perception of the research area, resulting from making new hypotheses, setting new goals, and perfecting the research methodology. These stages are reflected in the gradual transition from descriptions of the object of research and explanations of its formation processes to the creation of models and construction of theories. Thus, a need emerges to take up efforts to create the theory of industrial geography. It results not only from the willingness to intensify the elementary research, but also from social demands that use the results of scientific research in practical application, e.g. in building developmental strategies for national, regional, or local systems. 
Basing on the above assumptions, the author of this paper attempts at determining selected research problems in industrial spatial structure. The presented idea refers to the general assumptions of scientific methodology and the theory of systems, to a series of theoretical works that focus on building the theory of geography, to the basics of building the theory of industrial geography, and to numerous empirical studies. The research problem area outlined in the paper is not exhaustive, as it does not include all issues vital in theory development and empirical studies in the field of industrial geography. Its further development should be oriented at explaining and evaluating diversities observed in the industrial spatial structure, but also at proposing rational directions of its further transformation. It seems that adopting this line of development will make industrial geography more competitive in comparison to other fields of science, and will enable the realization of practical application goals. 